\title{
PSYCHOLOGICAL OUTCOMES OF CYBER-VIOLENCE ON VICTIMS, PERPETRATORS AND PERPETRATORS/VICTIMS
}

\author{
DANIELA ŠINCEK, IVANA DUVNJAK, MARIJA MILIĆ \\ Faculty of Humanities and Social Sciences, University of Osijek, Croatia. Contact: dsincek@ffos.hr
}

Received: 28.06.2017.

Accepted: 06.11.2017.

Original scientific paper

UDK: 364.271-053.2: 004.738.5

\begin{abstract}
Adolescents can take different roles in cyber-violence, and one of the most common classifications recognises victims, perpetrators, perpetrators/victims and uninvolved individuals. These groups experience some common outcomes, but there are also psychological outcomes that are specific to a particular role. In the relevant literature, depressive symptoms and low self-esteem are found as common outcomes for both victims and perpetrators, while distress is related only to being a victim. Since perpetrators/ victims display both types of roles in cyber-violence, they are assumed to be the group with the most negative outcomes, the group that per se experiences lower academic achievement. In the present research, youths with different roles in cyber-violence were compared regarding various psychological outcomes (depressive symptoms, stress, anxiety and self-esteem), hours spent on the Internet and academic achievement. In total, 1,176 participants were divided into groups of victims, perpetrators, perpetrators/ victims and uninvolved individuals. Perpetrators/victims differed in all variables from uninvolved individuals and had more negative results, supporting the claim that they constitute the group with the most negative outcomes, followed by victims. Perpetrators only showed a higher level of stress and had lower grades than the uninvolved group, suggesting lower costs of committing cyber-violence than experiencing it. The results provide insights into psychological outcomes, suggesting that perpetrators/victims comprise the group that should be included in selective or even indicated prevention programmes focused on reducing involvement in cyberviolence and its known outcomes, especially depression, anxiety and stress. Indicated prevention programmes for perpetrators should probably be tailored differently, for example, by problematising the lack of guilt and promoting empathy for victims while reducing the positive outcomes of cyber-violence (e.g., gaining social status via violence).
\end{abstract}

Keywords: cyber-violence, depression, anxiety, stress, self-esteem, adolescents

\section{INTRODUCTION}

Social media, nowadays, is present and accessible to most of youth in Croatia. It has become a new norm of communication among youth. This kind of communication, although it has many advantages and provides new and more attractive ways of communicating, also has its negative sides. It has become a vector for youth violence (Patton et al., 2014) and introduced new forms of violence that occur exclusively online (Peterson and Densley, 2017). Cyber-bullying and harassment, as forms of cyber-violence, have become common among juvenile populations (Hinduja and Patchin, 2008b; Lim et al., 2012).

Cyber-violence is a broader term than cyber-bullying and refers to harmful activities using information-communication technologies (ICT), e.g. harassment, insult, rumours, cyber-bullying
(Hanewald, 2008), trolling (destructive and deceptive behaviour to disrupt a space for no apparent purpose) (Buckels et al., 2014), and cyber-stalking (Beech et al., 2008). Some authors state that there are different forms of cyber-violence, e.g. Herring (2002) stated four forms: on-line contact that leads to off-line harms, cyber-stalking, online harassment and degradation.

It seems that cyber-violence is a more prevalent phenomenon than traditional violence and bullying since it can occur at any time (Willard, 2006). Although the two types of violence share some characteristics, they differ in some respects; a victim of cyber-violence often cannot know who the perpetrator is due to the nature of ICT, and not knowing from whom to expect harm can induce higher levels of anxiety. Most of the research conducted up to date has explored cyber-bullying (Peterson and Densley, 2017). 
The prevalence of cyber-bullying ranges from $10 \%$ to $35 \%$ (Kowalski and Limber, 2007; Li, 2007). In the Health Behaviour in Schoolaged Children study (Inchley and Currie, 2013), cyber-bullying was measured as behaviour that occurred at least two or three times a month in the previous couple of months. The prevalence of being bullied was about $12 \%$ of male adolescents and $10 \%$ of female adolescents, and the prevalence of being the bully was about $11 \%$ of male adolescents and $6 \%$ of female adolescents. Olweus (2012) stated that researchers and authors often exaggerate the frequency of cyber-bullying and its increase. It should be noted that there are many definitions of cyber-violence and related phenomena, e.g. cyber-bullying, cyber-harassment and cyber-aggression, and that these definitions are often inconsistent. The same can be stated for methodological approaches to measuring these phenomena, which explains the wide range in reported prevalence. Since cyber-violence is a broader term, it is reasonable to accept broader ranges of prevalence for it. There is a considerable lack of data concerning cyber-violence prevalence, but some research (e. g. Pornari and Wood, 2010) found prevalence of cyber-aggression to exceed $50 \%$. Juvonen and Gross (2008) surveyed those who experienced violent behaviour online at least once in the preceding year, and found that $72 \%$ had experienced cyber-violence. Kowalski et al. (2014) indicated that some studies purport to measure cyber-bullying, but include survey items that omit a perpetrator's intent to harm or that cover behaviours that are occasional. Such a study, even if it purports to explore cyber-bullying, is actually exploring cyber-violence. For example, behaviour such as excluding someone from cyber-groups may be unintentional from the point of view of the "perpetrator", but the victim can easily attribute intent to such an act and experience the same type of psychological outcomes as if the perpetrator had done it on purpose. For these reasons, in the present study, a broader definition of behaviour, e.g. cyber-violence, was used.

Cyber-victimisation has been related to negative outcomes, such as anxiety and lower academic achievement (Foody et al., 2015), and it has negative consequences for the psychological, social and physical health of all involved (Tokunaga, 2010). Some researchers consider any such behaviours, even if they appear only once, as an indicator of cyber-victimisation (Grigg, 2010).

Perpetrators often do not perceive their own behaviour as harassing and do not recognise the impact of their behaviour on the victims (Campbell et al., 2013). On the other hand, perpetrators do experience higher levels of stress, depression and anxiety than those uninvolved in cyber-violence. Other research findings contradict this view, suggesting that perpetrators are typical children or adolescents who have no behavioural problems (Cassidy et al., 2009; Kowalski et al., 2012; Patchin and Hinduja, 2012).

During adolescence, which is known as the stage of identity development, young people seek situations in which they can evaluate themselves positively. A large amount of research shows that involvement in cyber-violence has a negative effect on development in adolescence (Haynie et al., 2001; Juvonen et al., 2003). There are consistent findings that victims tend to have lower self-esteem than their peers who are not victims (Egan and Perry, 1998; Wild et al., 2004). These results could be explained by the fact that the experience of being a victim decreases one's self-esteem or that those with low self-esteem are more likely to be targeted as victims (Egan and Perry, 1998). Regarding perpetrators, the findings are inconsistent. Some studies show that perpetrators have either higher self-esteem (e.g., Salmivalli et al., 1999) or lower self-esteem (e.g., Yang et al., 2006) than uninvolved individuals; other studies even find no difference between perpetrators and non-perpetrators (Seals and Young, 2003). The worst outcomes are for the groups of victims/bullies, who are found in both cyber- and traditional violence (Kowalski and Limber, 2013).

Overall, research confirms both psychological and academic effects of cyber-violence. Victims experience feelings of anxiety, fear and sadness, which affect their learning and attitude towards school (Beran and Li, 2005). Furthermore, Mitchell et al. (2007) reveal that adolescents experiencing cyber-violence show significantly higher levels of depression and substance use. 
As stated, there are some contradictory findings, especially regarding the outcomes for perpetrators compared to uninvolved individuals. Therefore, the purpose of this study was to investigate the negative psychological outcomes that may arise from experiencing or committing cyber-violence.

\section{OBJECTIVES}

This study aimed to examine the prevalence of committing and experiencing cyber-violence; the involvement of different genders in cyber-violence; and differences in age, gender, grades and number of devices among the different roles of victims, perpetrators, perpetrators/victims and uninvolved individuals. Also, we wanted to examine differences in psychological outcomes (depression, anxiety, stress, self-esteem) as well as differences in Internet use among the different roles.

\section{HYPOTHESES}

The levels of psychological outcomes - depression, anxiety and stress - would be higher for adolescents involved in cyber-violence. Victims/perpetrators would experience the most unfavourable outcomes, followed by victims and perpetrators.

\section{METHODS}

\section{Participants}

Data were collected as part of a Croatian national study on children's and adolescents' habits of using ICT, in particular as part of a project focused on cyber-violence. Since there are many relevant correlates of cyber-violence, and it would be too exhausting for adolescents to fill out questionnaires for more than 45 minutes, separate sets of questionnaires were made. Each set had a common part (questionnaires about cyber-violence, self-disclosure on the Internet and self-esteem), but other questionnaires in each set differed: set A included questionnaires about subjects' own Facebook usage and perception of peers' Facebook usage; set B included questionnaires about depression, anxiety, stress and empathy; set $\mathrm{C}$ included questionnaires about traditional bullying and pathological gaming; set D included questionnaires about parental mediation and knowledge about cyber-violence; and set $\mathrm{E}$ included questionnaires about proneness to violent behaviour on the Internet under different conditions of anonymity. The total sample was sampled using non-proportional quota sampling from 84 schools across Croatia. For every county, we included one elementary school from a larger town and one from a smaller town/village; we also included high schools (gymnasium and vocational high school). Questionnaires were randomly distributed such that in every class, the first child filled out set A; the second child, set B; the third child, set $C$; the fourth child, set D; the fifth child, set $\mathrm{E}$; the sixth child, set A; and so on. This gave a subsample of $20 \%$ of all participants for the present paper. Thus, of the total sample of 7,038 children and youth from different elementary and high schools in both rural and urban areas, 1,176 children and adolescents filled out set B. Ages of participants in this subsample ranged from 11 to $20(M=14.75, S D=2.242)$. In terms of gender, 578 participants identified as male $(49.1 \%)$. All students were either in the sixth grade $(25.3 \%)$ or eighth grade $(25.9 \%)$ of elementary school, or in the second year $(27.1 \%)$ or fourth year $(21.7 \%)$ of high school.

\section{Measures}

Major sociodemographic information was collected on age, gender, grades, number of real friends, mothers' and fathers' education, Internet availability, number of devices, hours spent on the Internet per day on weekdays and on weekends.

The Committing and Experiencing Cyberviolence Scale (CECVS; Šincek, Tomašić Humer, Duvnjak, and Milić, 2015) is an adaptation of Cetin et al.'s (2011) scale. General statements from the original scale were concretised (e.g., the item "gossip on the Internet" was replaced with "I gossip about others on the Internet"). Some behaviours that were more relevant to children and adolescents, such as "They wanted me off or I was excluded from a group on the Internet", were added to the scale. The committing violence subscale included 21 questions, and the experiencing violence subscale consisted of 22 items. The participants were asked to rate the frequency of experiencing/committing violence on a 5-point Likert-type scale (1 $=$ never, $5=$ always). Higher scores indicated that 
the participants experienced/committed particular behaviours more frequently. The calculated internal consistency coefficient was $\alpha=0.90$ for experiencing violence and $\alpha=0.91$ for committing violence.

The Depression Anxiety Stress Scales (DASS - 21, Lovibond and Lovibond, 1995) is a 21-item, self-administered questionnaire divided into three scales, each with seven items, which measure the levels of three negative emotional states: depression, anxiety and stress. The Depression Scale refers to dysphoria, hopelessness, devaluation of life, self-deprecation, apathy and lack of interest. The Anxiety Scale assesses autonomic arousal and situational anxiety. The Stress Scale includes levels of chronic non-specific arousal and assesses difficulty in relaxing, being easily upset/agitated and being impatient. The items were answered using a 4-point Likert scale $(1=$ does not apply to me at all, $4=$ applies to me very much or most of the time) to rate the extent to which they had experienced each state over the preceding week. A higher score represents greater distress. The reliability coefficients (Cronbach's $\alpha$ ) were 0.83 for depression, 0.78 for anxiety and 0.84 for stress.

The Rosenberg Self-esteem Scale (RSE, Rosenberg, 1965) is a 10-item, self-reporting, unidimensional measure used to assess global self-esteem (e.g., "I feel that I am a person of worth, at least on an equal plane with others"). The items were answered on a 4-point scale $(1=$ strongly disagree, $4=$ strongly agree). The scores ranged from 10 to 40, with higher scores indicating higher self-esteem. Cronbach's $\alpha$ was 0.80 .

\section{Procedure}

The research was approved by the ethics committee of the Department of Psychology, Faculty of Humanities and Social Sciences. Informed consent was obtained from the participants and their parents. Data were collected at the participants' schools during their regularly scheduled class times. The researcher distributed the surveys in a paper-and-pencil format, and the students completed them independently and anonymously. Since the collection was part of a larger study, different sets of questionnaires were given to different students in a randomized way. The full survey took approx- imately 45 minutes to complete, after which the students were given a small thank-you gift (a pen, a pencil or other small item).

\section{Statistical analyses}

Data were analysed using the statistical package SPSS version 20.0 (IBM, Chicago, IL, USA). Descriptive statistical parameters were shown, reliability tests were conducted using Cronbach's $\alpha$ test, and a one-way analysis of variance (ANOVA) was used to process the results.

\section{RESULTS}

\section{Prevalence of committing and experiencing cyber-violence and involvement in cyber- violence as a function of age, gender, grades and number of devices}

Based on the results about committing and experiencing cyber-violence, participants were classified into four groups as follows: victims ( $n$ $=183)$, perpetrators $(n=93)$, perpetrators/victims $(n=151)$ and uninvolved $(n=749)$. More than half of the participants (64\%) were not involved in cyber-violence, $15 \%$ were victims, $13 \%$ were perpetrators/victims and $8 \%$ were perpetrators. Furthermore, the students who identified as perpetrators/victims ( $15.7 \%$ were male and $9.8 \%$ female) were the oldest and had the lowest grades/school achievement.

Regarding age, the youngest participants were the least involved in cyber-violence $(M=14.52, S D$ $=2.25$ ), and the oldest were the most involved as perpetrators/victims $(M=15.62, S D=2.10)$. The average age of victims was $M=14.60(S D=2.18)$, and that of perpetrators was $M=15.41(S D=2.05)$.

In the present study, more female participants $(67 \%)$ were not involved in cyber-violence than male $(61 \%)$ participants. There were also slightly more female victims (17\%) than male victims (14\%). More male participants were perpetrators $(10 \%)$ and perpetrators/victims (16\%) than female perpetrators $(6 \%)$ and perpetrators/victims $(10 \%)$.

Adolescents who were not involved in cyber-violence had the highest grades $(M=4.07, S D=$ 0.79 ), while perpetrators/victims had the lowest 
grades $(M=3.78, S D=0.87)$. The average grades were $M=3.82(S D=0.87)$ for perpetrators and $M$ $=3.92(S D=0.78)$ for victims.

Participants most frequently reported having six devices in their homes (Mode $=6, M=6.56$, $S D=3.15)$.

\section{Differences in age, gender, grades and number of devices among the different roles}

Table 1 shows the differences among the four groups in terms of age, grades and number of devices, explored via ANOVA. Post-hoc tests were conducted in order to examine the differences in age, grades and number of devices among the different roles.

Regarding age, victims and individuals uninvolved in cyber-violence were significantly younger than perpetrators and perpetrators/victims, and victims were significantly younger than perpetrators $\left(F_{(3,1168)}=13.57, p<0.01\right)$. Perpetrators/victims and perpetrators had significantly lower academic achievement $\left(F_{(3,1165)}=7.85, p<0.01\right)$ than uninvolved participants. Participants who were not involved and victims had significantly fewer devices than perpetrators/victims $\left(F_{(3,1149)}=3.23, p<0.05\right)$.

A chi-squared test of independence was performed to examine the relationship between involvement in cyber-violence and gender (Table $2)$. The relationship between these variables was significant: $\chi^{2}(3)=17.59, p<0.01$. Comparing the expected and observed frequencies of involvement in cyber-violence among different roles and genders indicated that female participants were more likely to become victims and were less involved in cyber-violence than male participants. Male participants were more likely to become perpetrators and perpetrators/victims than female participants.

\section{Differences in psychological outcomes for victims, perpetrators, perpetrators/victims and uninvolved individuals}

Results show that perpetrators/victims had the highest negative outcomes (Table 3). This group had higher levels of depression $(M=1.96, S D=$ $0.76)$, anxiety $(M=1.87, S D=0.66)$ and stress $(M$ $=2.48, S D=0.75)$ than the other groups, as well as a lower level of self-esteem $(M=29.09, S D=$

Table 1. Differences in age, grades and number of devices among the different roles in cyber-violence

\begin{tabular}{|c|c|c|c|c|c|c|c|c|c|}
\hline Variable & Role & $N$ & Min & $\operatorname{Max}$ & $M$ & $S D$ & $F$ & $d f$ & $p$ \\
\hline \multirow[t]{4}{*}{ Age } & Uninvolved & 746 & 11 & 20 & 14.52 & 2.25 & \multirow[t]{4}{*}{13.57} & \multirow[t]{4}{*}{3,1168} & \multirow[t]{4}{*}{.00} \\
\hline & Victim & 182 & 11 & 18 & 14.60 & 2.17 & & & \\
\hline & Perpetrator & 93 & 11 & 19 & 15.41 & 2.05 & & & \\
\hline & Perpetrator/victim & 151 & 11 & 20 & 15.62 & 2.10 & & & \\
\hline \multirow[t]{4}{*}{ Grades } & Uninvolved & 743 & 1 & 5 & 4.07 & 0.79 & \multirow[t]{4}{*}{7.85} & \multirow[t]{4}{*}{3,1165} & \multirow[t]{4}{*}{.00} \\
\hline & Victim & 183 & 1 & 5 & 3.91 & 0.75 & & & \\
\hline & Perpetrator & 93 & 1 & 5 & 3.82 & 0.87 & & & \\
\hline & Perpetrator/victim & 150 & 1 & 5 & 3.78 & 0.86 & & & \\
\hline \multirow{4}{*}{$\begin{array}{l}\text { Number of } \\
\text { devices }\end{array}$} & Uninvolved & 734 & 0 & 15 & 6.34 & 2.76 & \multirow[t]{4}{*}{3.23} & \multirow[t]{4}{*}{3,1149} & \multirow[t]{4}{*}{.02} \\
\hline & Victim & 180 & 1 & 15 & 6.26 & 2.94 & & & \\
\hline & Perpetrator & 89 & 2 & 15 & 6.36 & 2.47 & & & \\
\hline & Perpetrator/victim & 150 & 1 & 15 & 7.07 & 2.81 & & & \\
\hline
\end{tabular}

Table 2. Results of chi-square test for gender and involvement in cyber-violence among the different roles

\begin{tabular}{|c|c|c|c|c|c|}
\hline & \multicolumn{2}{|c|}{ Gender } & \multirow[t]{3}{*}{$\chi^{2}$} & \multirow[t]{3}{*}{$p$} \\
\hline & & Male & Female & & \\
\hline & & Count (Expected Count) & Count (Expected Count) & & \\
\hline \multirow[t]{4}{*}{ Role } & Uninvolved & $350(368.2)$ & $396(377.8)$ & \multirow[t]{4}{*}{17.59} & \multirow[t]{4}{*}{.00} \\
\hline & Victim & $80(90.3)$ & $103(92.7)$ & & \\
\hline & Perpetrator & $57(45.9)$ & $36(47.1)$ & & \\
\hline & Perpetrator/victim & $91(73.5)$ & $58(75.5)$ & & \\
\hline
\end{tabular}


6.35). Victims had higher levels of depression $(M=$ $1.75, S D=0.67)$ and anxiety $(M=1.78, S D=0.66)$ and lower self-esteem $(M=29.64, S D=6.39)$ than perpetrators, but perpetrators had a higher level of stress $(M=2.10, S D=0.72)$.

In order to examine differences in depression, anxiety, stress and self-esteem among different roles, we conducted ANOVA. Post-hoc tests were also conducted in order to examine differences among particular roles. Statistically significant differences were found in depressive symptoms $\left(F_{(3,1120)}=31.75, p<0.01\right)$ : victims displayed more symptoms than the uninvolved group, and perpetrators/victims manifested more symptoms than the other three groups.

Those uninvolved in cyber-violence showed significantly lower levels of anxiety than victims and perpetrators/victims; perpetrators showed lower levels than perpetrators/victims $\left(F_{(3,1137)}\right.$ $=24.13, p<0.01)$. Uninvolved participants had the lowest level of stress among the four groups $\left(F_{(3,1125)}=46.92, p<0.01\right)$, while perpetrators/victims indicated more signs of stress than victims and perpetrators. Perpetrators/victims had significantly lower levels of self-esteem than the uninvolved group $\left(F_{(3,1161)}=5.45, p<0.01\right)$, with insignificant differences among the other groups.

\section{Internet use by victims, perpetrators, perpetrators/victims and uninvolved individuals}

Regarding variables related to Internet use (Table 4), most of the participants from the group of perpetrators/victims stated that the Internet was constantly available to them $(M=1.23, S D=0.55$; a smaller value means more Internet availability). This group also spent the most time per day on the Internet, on weekdays $(M=6.64, S D=5.33)$ and on weekends $(M=9.18, S D=6.34)$.

Perpetrators/victims and perpetrators spent significantly more time on the Internet on weekdays $\left(F_{(3,1152)}=17.65, p<0.01\right)$ and weekends $\left(F_{(3,1152)}\right.$ $=25.16, p<0.01)$ than the uninvolved group. On weekdays and weekends, perpetrators/victims spent more time on the Internet than victims, while victims spent more time on the Internet on weekdays than the uninvolved group.

\section{DISCUSSION}

Based on the results of this research, the participants were classified into four groups, and $64 \%$ of participants were not involved in cyber-violence, $15 \%$ were victims, $13 \%$ were perpetrators/victims and $8 \%$ were perpetrators. Similar findings were obtained in Kowalski and Limber's (2007) study: $11 \%$ were victims, $7 \%$ were perpetrators/victims

Table 3. Descriptive statistics and results of ANOVA for different psychological outcomes in victims, perpetrators, perpetrators/victims and uninvolved individuals

\begin{tabular}{|c|c|c|c|c|c|c|c|c|c|}
\hline Variable & Role & $N$ & Min & $\operatorname{Max}$ & $M$ & $S D$ & $F$ & $d f$ & $p$ \\
\hline \multirow[t]{4}{*}{ Depression } & Uninvolved & 724 & 1 & 4.00 & 1.47 & 0.55 & \multirow[t]{4}{*}{31.75} & \multirow[t]{4}{*}{3,1120} & \multirow[t]{4}{*}{.00} \\
\hline & Victim & 173 & 1 & 3.71 & 1.75 & 0.67 & & & \\
\hline & Perpetrator & 85 & 1 & 3.43 & 1.66 & 0.64 & & & \\
\hline & Perpetrator/victim & 142 & 1 & 3.86 & 1.96 & 0.76 & & & \\
\hline \multirow[t]{4}{*}{ Anxiety } & Uninvolved & 730 & 1 & 4.00 & 1.51 & 0.51 & \multirow[t]{4}{*}{24.13} & \multirow[t]{4}{*}{3,1137} & \multirow[t]{4}{*}{.00} \\
\hline & Victim & 175 & 1 & 4.00 & 1.78 & 0.66 & & & \\
\hline & Perpetrator & 91 & 1 & 3.57 & 1.66 & 0.56 & & & \\
\hline & Perpetrator/victim & 145 & 1 & 3.86 & 1.87 & 0.66 & & & \\
\hline \multirow[t]{4}{*}{ Stress } & Uninvolved & 725 & 1 & 4.00 & 1.77 & 0.65 & \multirow[t]{4}{*}{46.92} & \multirow[t]{4}{*}{3,1125} & \multirow[t]{4}{*}{.00} \\
\hline & Victim & 177 & 1 & 4.00 & 2.08 & 0.76 & & & \\
\hline & Perpetrator & 87 & 1 & 3.71 & 2.10 & 0.72 & & & \\
\hline & Perpetrator/victim & 140 & 1 & 4.00 & 2.48 & 0.75 & & & \\
\hline \multirow[t]{4}{*}{ Self-esteem } & Uninvolved & 741 & 7 & 40 & 30.89 & 5.72 & \multirow[t]{4}{*}{5.45} & \multirow[t]{4}{*}{3,1161} & \multirow[t]{4}{*}{.00} \\
\hline & Victim & 181 & 10 & 40 & 29.64 & 6.39 & & & \\
\hline & Perpetrator & 92 & 11 & 40 & 29.75 & 6.32 & & & \\
\hline & Perpetrator/victim & 151 & 12 & 40 & 29.09 & 6.35 & & & \\
\hline
\end{tabular}


Table 4. Descriptive statistics and results of ANOVA on variables regarding Internet use by victims, perpetrators, perpetrators/victims and uninvolved individuals

\begin{tabular}{|c|c|c|c|c|c|c|c|c|c|}
\hline Variable & \begin{tabular}{|l|} 
Role \\
\end{tabular} & $N$ & Min & $\operatorname{Max}$ & $M$ & $S D$ & $F$ & $d f$ & $p$ \\
\hline \multirow{4}{*}{$\begin{array}{l}\text { Internet } \\
\text { availability }\end{array}$} & Uninvolved & 746 & 1 & 4 & 1.52 & 0.78 & \multirow[t]{4}{*}{10.11} & \multirow[t]{4}{*}{3,1166} & \multirow[t]{4}{*}{.00} \\
\hline & Victim & 181 & 1 & 4 & 1.34 & 0.65 & & & \\
\hline & Perpetrator & 93 & 1 & 4 & 1.29 & 0.60 & & & \\
\hline & Perpetrator/victim & 150 & 1 & 4 & 1.23 & 0.55 & & & \\
\hline \multirow{4}{*}{$\begin{array}{l}\text { Hours per day } \\
\text { spent on the } \\
\text { Internet on } \\
\text { weekdays }\end{array}$} & Uninvolved & 739 & 0 & 24 & 3.98 & 3.95 & \multirow[t]{4}{*}{17.65} & \multirow[t]{4}{*}{3,1152} & \multirow[t]{4}{*}{.00} \\
\hline & Victim & 180 & 0 & 24 & 4.88 & 4.54 & & & \\
\hline & Perpetrator & 90 & 0.30 & 24 & 5.53 & 4.59 & & & \\
\hline & Perpetrator/victim & 147 & 0 & 24 & 6.64 & 5.33 & & & \\
\hline \multirow{4}{*}{$\begin{array}{l}\text { Hours per day } \\
\text { spent on the } \\
\text { Internet on } \\
\text { weekends }\end{array}$} & Uninvolved & 738 & 0 & 30 & 5.45 & 4.67 & \multirow[t]{4}{*}{25.16} & \multirow[t]{4}{*}{3,1152} & \multirow[t]{4}{*}{.00} \\
\hline & Victim & 181 & 0 & 24 & 6.69 & 5.25 & & & \\
\hline & Perpetrator & 89 & 0 & 36 & 7.66 & 5.65 & & & \\
\hline & Perpetrator/victim & 148 & 0 & 24 & 9.18 & 6.34 & & & \\
\hline
\end{tabular}

and $4 \%$ were perpetrators. Some studies show that cyber-violence (as well as physical bullying) is most frequent in middle school and decreases in high school, while verbal bullying is also the most prevalent in middle school and remains high during high school (Williams and Guerra, 2007). In this research, victims and uninvolved participants were younger than perpetrators and perpetrators/victims. In comparison, based on their research, Vandebosch and Van Cleemput (2009) state that younger children are more often victims and bystanders of cyber-bullying, and adolescents who are perpetrators are more dependent on the Internet and take more related risks.

Regarding characteristics in this study, perpetrators/victims were the oldest and more often male, and they had the lowest grades/school achievement. Some studies show that perpetrators/victims, especially males, experience the strongest psychosomatic effects, such as headaches, sleeping difficulties and physical symptomatology (e.g., Agatston et al., 2012). Other research findings differ regarding gender: some studies (e.g., Aricak et al., 2008; Li, 2006) suggest that male participants are more likely to be cyber-bullies, but other studies do not find any gender difference (Slonje and Smith 2008; Williams and Guerra, 2007). Wang et al. (2009) and Kowalski and Limber (2007) report that girls are more likely to be victims of cyber-violence, and that boys tend to be perpetrators. There are also gender differences in the types of violence experienced, with girls stating that they experience more exclusion, gender-based harassment and others posting personal information about them (Jackson et al., 2009). Therefore, girls believe that their reputation is damaged by such cyber-violence, which affects their relationships with friends, and generally, they experience many negative consequences.

Many studies show the negative impact of cyber-violence on academic performance, including reduced concentration, school avoidance, isolation, lower academic achievement and higher risk of school problems (Hinduja and Patchin, 2007, 2008a; Marczak and Coyne, 2010). Greater frequency and intensity appear in the group of perpetrators/victims, and they feel less safe at school, have lower self-esteem and have more suicidal thoughts (Patchin and Hindjua, 2012). However, other research indicates no such differences. For example, in the study by Zhou et al. (2013), no differences were found in school performance between high school students who engaged or did not engage in cyber-violence.

We found that perpetrators/victims had the highest negative outcomes. They had higher levels of depression, anxiety and stress than other groups, as well as a lower level of self-esteem. These results, indicating that perpetrators/victims constitute the group that is at highest risk for psychosocial problems, confirm the findings of another study (Juvonen et al., 2003). In the present study, victims displayed significantly more depressive symptoms than the uninvolved group, and perpetrators/victims manifested more symp- 
toms than the other three groups. Pellegrini (1998) showed that depression is associated with exposure to bullying. Wang et al. (2011) state that adolescents who are involved in violence have a higher level of depression. Furthermore, they found that victims of cyber-violence reported a higher level of depression than perpetrators or perpetrators/victims. These findings can be explained by the fact that victims of cyber-violence may be more likely to feel helpless and isolated when experiencing an anonymous attack through a social network or in some other way (Smith et al., 2008). It is possible that victims are unable to find out the perpetrators' identities or lack knowledge about what to do in that situation.

In the present study, those uninvolved in cyber-violence showed significantly lower levels of anxiety than victims and perpetrators/victims; perpetrators also demonstrated lower levels of anxiety than perpetrators/victims. Uninvolved participants had significantly lower levels of stress than the other groups, while perpetrators/victims had significantly more signs of stress than victims and perpetrators. Perpetrators/victims had significantly lower levels of self-esteem than the uninvolved. Kowalski and Limber (2007) found that students in grades 6-12 who both bullied and were victimised were more anxious, depressed and had lower self-esteem. The impact of cyber-violence also depends on personal experience, and the impact is greater on victims than on perpetrators (Cassidy, 2013). Victims most often experience feelings of sadness, hurt, anger, frustration, stress and loneliness, prolonged depression, low self-esteem, social anxiety and emotional and peer problems (Agatston et al., 2012; Kowalski et al., 2012; Marczak and Coyne, 2010; Menesini and Nocentini, 2012; Patchin and Hinduja, 2012; Smith, 2012; Sourander et al., 2010; Tokunaga, 2010). The relevant literature shows that perpetrators/victims experience the worst psychological effects because they are simultaneously engaged in cyber-violence as perpetrators and victims (Kowalski et al., 2012).

On weekends and weekdays, perpetrators/victims spent more time on the Internet than victims in the present study, while victims spent more time on the Internet on weekdays than uninvolved par- ticipants. In his study, Erdur-Baker (2010) found that risky Internet use and usage frequency significantly predicted both cyber-victimisation and cyber-violence for male and female students. Frequent usage was also a better predictor of both cyber-victimisation and cyber-violence for female students, whereas risky Internet use was a better predictor among male students since girls were less involved in risky Internet use and generally more cautious.

\section{STRENGTHS AND LIMITATIONS OF THE STUDY}

The data from this research provide insights into prevalence and involvement in committing and experiencing cyber-violence and highlight the importance of different psychological outcomes of cyber-violence. The additional value of this study is that it provides a perspective considering different roles that adolescents have in cyber-violence. Possible explanations of the obtained results can be found in the limitations of the research. For all measures, self-assessment was used. It is recommended that future studies use different additional objective measures, such as peer estimation about Internet use. The correlational nature of the present study prevents us from establishing causal relationships between committing or experiencing cyber-violence and psychological outcomes. Other factors such as loneliness should be explored simultaneously in future studies in order to better understand the possible adverse consequences.

In the future, longitudinal studies should be conducted to complete the outcomes of cyber-violence for all involved groups, using a multi-source approach as a tool to acquire more precise information. For example, it is possible for a victimised child to be unable to recognise that he or she is being victimised or to take the view of his or her bully and blame him- or herself for not being good enough. Therefore the relevant information must be obtained from parents or teachers. Another possibility is that others perceive some forms of victimisation as not too serious, but the child would know that his or her pain is real. Some insights about becoming perpetrators/victims could also be gained through longitudinal studies. 


\section{CONCLUSION}

Children and adolescents today are involved in cyberspace, which may lead to adverse consequences. They rely on the Internet for many things, including for interactions and social connections. It is essential to understand the psychological outcomes of cyber-violence for children and adolescents in order to provide guidance and prevent negative outcomes. Based on the obtained results of this research, we can conclude that the group of perpetrators/victims has the most negative psychological outcomes and low academic achievement. Therefore, to effectively plan preventive activities for children and adolescents, we should take account of the characteristics of perpetrators/ victims, perpetrators and victims, as well as the outcomes that arise from cyber-violent behaviours. Our results suggest that perpetrators/victims should be included in selective or even indicated prevention programmes focused on reducing involvement in cyber-violence and its known outcomes, especially depression, anxiety and stress. Indicated prevention programmes for perpetrators should probably be tailored differently, such as by problematising the lack of guilt and promoting empathy for victims, while reducing the positive outcomes of cyber-violence (e.g., gaining social status via violence). 


\section{LITERATURE}

Agatston, P., Kowalski, R. \& Limber, S. (2012): Youth views on cyberbullying. In: J. W. Patchin, S. Hinduja (Eds.), Cyberbullying prevention and response: Expert perspectives (pp.57-71). New York NY: Routledge.

Aricak, T., Siyahhan, S., Uzunhasanoglu, A., Saribeyoglu, S., Ciplak, S., Yilmaz, N. \& Memmedov, C. (2008): Cyberbullying among Turkish adolescents, CyberPsychology \& Behavior, 11, 3, 253-261.

Beech, A. R., Elliott, I. A., Birgden, A. \& Findlater, D. (2008): The internet and child sexual offending: A criminological review, Aggression and Violent Behavior, 13(3), 216-228.

Beran, T. \& Li, Q. (2005): Cyber-harassment: A study of a new method for an old behavior, Journal of Educational Computing Research, 32, 3, 265-277.

Buckels, E. E., Trapnell, P. D. \& Paulhus, D. L. (2014): Trolls just want to have fun, Personality and Individual Differences, 67, 97-102.

Campbell, M. A., Slee, P. T., Spears, B., Butler, D., \& Kift, S. (2013): Do cyberbullies suffer too? Cyberbullies' perceptions of the harm they cause to others and to their own mental health, School Psychology International, $34,6,613-629$.

Cassidy, W., Faucher, C. \& Jackson, M. (2013): Cyberbullying among youth: A comprehensive review of current international research and its implications and application to policy and practice, School Psychology International, $34,6,575-612$.

Cassidy, W., Jackson, M. \& Brown, K. (2009): Sticks and stones can break my bones, but how can pixels hurt me? Students' experiences with cyber-bullying, School Psychology International, 30, 383-402.

Egan, S. K. \& Perry, D. G. (1998): Does low self-regard invite victimization?, Developmental psychology, 34, 2, 299-309.

Erdur-Baker, Ö. (2010): Cyberbullying and its correlation to traditional bullying, gender and frequent and risky usage of internet-mediated communication tools, New media \& society, 12, 1, 109-125.

Foody, M., Samara, M. \& Carlbring, P. (2015): A review of cyberbullying and suggestions for online psychological therapy, Internet Interventions, 2, 3, 235-242.

Grigg D. W. (2010): Cyber-aggression: Definition and concept of cyberbullying, Australian Journal of Guidance and Counseling, 20, 143-156.

Hanewald, R. (2008): Confronting the pedagogical challenge of cyber safety. Australian journal for teacher education, $33,3,1-16$.

Haynie, D. L., Nansel, T., Eitel, P., Crump, A. D., Saylor, K., Yu, K. \& Simons-Morton, B. (2001): Bullies, victims, and bully/victims: Distinct groups of at-risk youth, The Journal of Early Adolescence, 21, 1, 29-49.

Herring, S.C. (2002): Cyber violence: Recognizing and resisting abuse in online environments. Asian women, 14 , $187-212$.

Hinduja, S. \& Patchin, J. W. (2007): Offline consequences of online victimization: school violence and delinquency. Journal of School Violence, 6, 3, 89-112.

Hinduja, S., \& Patchin, J. W. (2008a): Bullying beyond the schoolyard: Preventing and responding to cyberbullying. Thousand Oaks CA: Corwin.

Hinduja, S. \& Patchin, J. W. (2008b): Cyberbullying: An exploratory analysis of factors related to offending and victimization, Deviant Behavior, 29, 129-156.

Huling B.A.B. (2011): Narcissism, Facebook use and self-disclosure. Thesis, Retrieved from BYU Scholars Archive (Accession No. 2475). 
Inchley, J., \& Currie, D. (2013): Growing up unequal: gender and socioeconomic differences in young people's health and well-being. Health Behaviour in School-aged Children (HBSC) study: international report from the 2013/2014 survey. Denmark: World Health Organization.

Jackson, M., Cassidy, W. \& Brown, K. N. (2009): You were born ugly and you'll die ugly too. Cyber-bullying as relational aggression, Education Journal: Special Issue on Technology and Social Media Part I, 15, 2.

Juvonen, J., Graham, S. \& Schuster, M. A. (2003): Bullying among young adolescents: The strong, the weak, and the troubled, Pediatrics, 112, 6, 1231-1237.

Juvonen, J., \& Gross, E. F. (2008): Extending the school grounds? Bullying experiences in cyberspace. Journal of School health, 78, 9, 496-505.

Kowalski, R. M., Giumetti, G. W., Schroeder, A. N., \& Lattanner, M. R. (2014): Bullying in the digital age: A critical review and meta-analysis of cyberbullying research among youth. retrieved on 26th October 2017 from https://www. researchgate.net/profile/Amber_Schroeder/publication/260151324_Bullying_in_the_Digital_Age_A_Critical_ Review_and_Meta-Analysis_of_Cyberbullying_Research_Among_Youth/links/546f5 $\bar{b} 6 \mathrm{a} 0 \mathrm{cf} 2 \overline{\mathrm{d}} 67 \mathrm{fc} 03 \overline{1} 10 \mathrm{ef5}$.pdf

Kowalski, R. M. \& Limber, S. P. (2007): Electronic bullying among middle school students, Journal of adolescent health, 41, 6, 22-30.

Kowalski, R. M., \& Limber, S. P. (2013): Psychological, physical, and academic correlates of cyberbullying and traditional bullying. Journal of Adolescent Health, 53, 1, S13-S20.

Kowalski, R. M., Morgan, C. A. \& Limber, S. P. (2012): Traditional bullying as a potential warning sign of cyberbullying, School Psychology International, 33, 5, 505-519.

Li, Q. (2006): Cyberbullying in schools: A research of gender differences, School psychology international, 27, 2, 157-170.

Li, Q. (2007): New bottle but old wine: A research of cyberbullying in schools, Computers in

Human Behavior, 23, 1777-1791.

Lim, S., Chan, Y., Vadrevu, S. \& Basnyat, I. (2012): Managing peer relationships online: Investigating the use of Facebook by juvenile delinquents and youths-at-risk, Computers in Human Behavior, 29, 8-15.

Marczak, M., \& Coyne, I. (2010): Cyberbullying at school: Good practice and legal aspects in the United Kingdom, Australian Journal of Guidance and Counselling, 20, 182-193.

Menesini, E. \& Nocentini, A. (2012): Peer education intervention: Face-to-face versus online. In: A. Costabile, B. A. Spears (Eds.), The impact of technology on relationships in educational settings (pp. 139-150). New York NY: Routledge.

Mitchell, K.J., Ybarra, M. \& Finkelhor, D. (2007): The relative importance of online victimization in understanding depression, delinquency and substance use, Child Maltreatment, 12, 4, 314-324.

Olweus, D. (2012): Cyberbullying: An overrated phenomenon?, European Journal of Developmental Psychology, 9, 5, 520-538.

Patchin, J. W., \& Hinduja, S. (2006): Bullies move beyond the schoolyard: A preliminary look at cyberbullying, Youth Violence and Juvenile Justice, 4, 2, 148-169.

Patchin, J. W. \& Hinduja, S. (2012): Cyberbullying: An update and synthesis of the research. In: J. W. Patchin, S. Hinduja (Eds.), Cyberbullying prevention and response: Expert perspectives (pp. 13-35). New York NY: Routledge.

Patton, D. U., Hong, J. S., Ranney, M., Patel, S., Kelley, C. \& Eschmann, R. (2014): Social media as a vector for youth violence: A review of the literature, Computers in Human Behavior, 35, 548-553.

Pellegrini, A. D. (1998): Bullies and victims in school: A review and call for research, Journal of Applied Developmental Psychology, 19, 2, 165-176. 
Peterson, J. \& Densely, J. (2017): Cyber violence: What do we know and where do we go from here?, Aggression and Violent Behavior, in press.

Pornari, C. D., \& Wood, J. (2010): Peer and cyber aggression in secondary school students: The role of moral disengagement, hostile attribution bias, and outcome expectancies. Aggressive Behaviour, 36, 2, 81-94.

Salmivalli, C., Kaukiainen, A., Kaistaniemi, L. \& Lagerspetz, K. M. (1999): Self-evaluated self-esteem, peer-evaluated self-esteem, and defensive egotism as predictors of adolescents' participation in bullying situations, Personality and Social Psychology Bulletin, 25, 10, 1268-1278.

Seals, D. \& Young, J. (2003): Bullying and victimization: Prevalence and relationship to gender, grade level, ethnicity, self-esteem, and depression, Adolescence, 38, 152, 735-747.

Slonje, R. \& Smith, P. K. (2008): Cyberbullying: another main type of bullying?, Scandinavian Journal of Psychology, $49,147-154$

Slonje, R., Smith, P. K. \& Frisén, A. (2013): The nature of cyberbullying, and strategies for prevention. Computers in Human Behavior, 29, 1, 26-32.

Smith, P. K. (2012): Cyberbullying and cyber aggression. In: S. R. Jimerson, A. B. Nickerson, M. J. Mayer, M. J. Furlong (Eds.), Handbook of school violence and school safety: International research and practice (2nd ed.) (pp. 93-103). New Yor NY: Routledge.

Smith, P. K., Mahdavi, J., Carvalho, M., Fisher, S., Russell, S. \& Tippett, N. (2008): Cyberbullying: Its nature and impact in secondary school pupils, Journal of child psychology and psychiatry, 49, 4, 376-385.

Sourander, A., Klomek, A. B., Ikonen, M., Lindroos, J., Luntamo, T. \& Koskelainen, M., et al. (2010): Psychosocial risk factors associated with cyberbullying among adolescents: A population-based study, Archives of General Psychiatry, 67, 720-728.

Tokunaga, R. S. (2010): Following you home from school: A critical review and synthesis of research on cyberbullying victimization, Computers in human behavior, 26,3, 277-287.

Vandebosch, H. \& Van Cleemput, K. (2009): Cyberbullying among youngsters: Profiles of bullies and victims, New media \& society, 11, 8, 1349-1371.

Wang, J., Iannotti, R. J. \& Nansel, T. R. (2009): School bullying among adolescents in the United States: Physical, verbal, relational, and cyber, Journal of Adolescent health, 45, 4, 368-375.

Wang, J., Nansel, T. R. \& Iannotti, R. J. (2011): Cyber and traditional bullying: Differential association with depression, Journal of adolescent health, 48, 4, 415-417.

Wild, L. G., Flisher, A. J., Bhana, A. \& Lombard, C. (2004): Associations among adolescent risk behaviours and self-esteem in six domains, Journal of child psychology and psychiatry, 45, 8, 1454-1467.

Willard, N. (2006): Cyberbullying and cyberthreats: responding to the challenge of online social cruelty, threats, and distress. Champaign IL: Center for Safe and Responsible Internet Use.

Williams, K. \& Guerra, N. (2007): Prevalence and predictors of Internet bullying, Journal of

Adolescent Health, 41, 6, 14-21.

Yang, S. J., Kim, J. M., Kim, S. W., Shin, I. S. \& Yoon, J. S. (2006): Bullying and victimization behaviors in boys and girls at South Korean primary schools, Journal of the American Academy of Child \& Adolescent Psychiatry, $45,1,69-77$.

Ybarra, M. L., \& Mitchell, K. J. (2007): Prevalence and frequency of internet harassment instigation: Implications for adolescent health. Journal of Adolescent Health, 41, 189-195.

Zhou, Z., Tang, H., Tian, Y., Wei, H., Zhang, F. \& Morrison, C. (2013): Cyberbullying and its risk factors among Chinese high school students, School Psychology International, 34, 630-647. 


\section{PSIHOLOŠKE POSLJEDICE NASILJA PREKO INTERNETA ZA ŽRTVE, NASILNIKE I NASILNIKE/ŽRTVE}

Sažetak: Adolescenti mogu imati različite uloge u nasilju putem interneta, a najčešća podjela je na žrtve, nasilnike, nasilnikel žrtve i pojedince neuključene u nasilje. Neke od posljedica za ove skupine su jednake, no postoje psihološke posljedice koje su specifične za pojedinu ulogu koju pojedinac ima u nasilju preko interneta. Relevantni nalazi pokazuju kako se depresivni simptomi i nisko samopoštovanje pojavljuju i kodžrtvi i kod nasilnika, dok se stres pojavljuje jedino kod žrtvi. Budući da skupina nasilnikal žrtvi iskazuje obje vrste uloga u nasilju preko interneta, pretpostavlja se kako je to skupina s najviše negativnih posljedica $i$ najlošijim obrazovnim uspjehom. U ovom istraživanju, uspoređeni su adolescenti koji imaju različite uloge u nasilju preko interneta s obzirom na različite psihološke posljedice (depresivni simptomi, stres, anksioznost $i$ samopoštovanje), sate provedene na internetu i obrazovni uspjeh. U istraživanju je sudjelovalo ukupno 1,176 sudionika koji su podijeljeni u skupine žrtvi, nasilnika, nasilnikal žrtvi i skupinu pojedinaca koji nisu uključeni u nasilje. Skupina nasilnika/žrtvi razlikuje se u svim mjerenim varijablama od skupine koja nije uključena u nasilje putem interneta i ima više negativnih posljedica, što je potvrda nalazima o tome kako ova skupina doživljava najviše negativnih posljedica, uz skupinu žrtvi. Nasilnici jedino pokazuju više razine stresa i imaju slabije ocjene nego skupina koja nije uključena u nasilje putem interneta, što upućuje na manje posljedice činjenja nego doživljavanja nasilja putem interneta. Dobiveni rezultati pružaju uvid u doživljene psihološke posljedice, ukazujući da su nasilnici/žrtve skupina koja bi trebala biti uključena u selektivne ili čak indicirane preventivne programe usmjerene na smanjivanje uključenosti u nasilje putem interneta, kao i posljedica, osobito depresivnosti, anksioznosti i stresa. Indicirani preventivni programi trebali bi biti prilagođeni ovoj skupini, na primjer raditi na nedostatku osjećaja krivnje i promicanju empatije za žrtve te smanjenju pozitivnih posljedica (npr. postizanje socijalnog statusa na temelju nasilja).

Ključne riječi: nasilje putem interneta, depresivnost, anksioznost, stres, samopoštovanje, adolescenti 